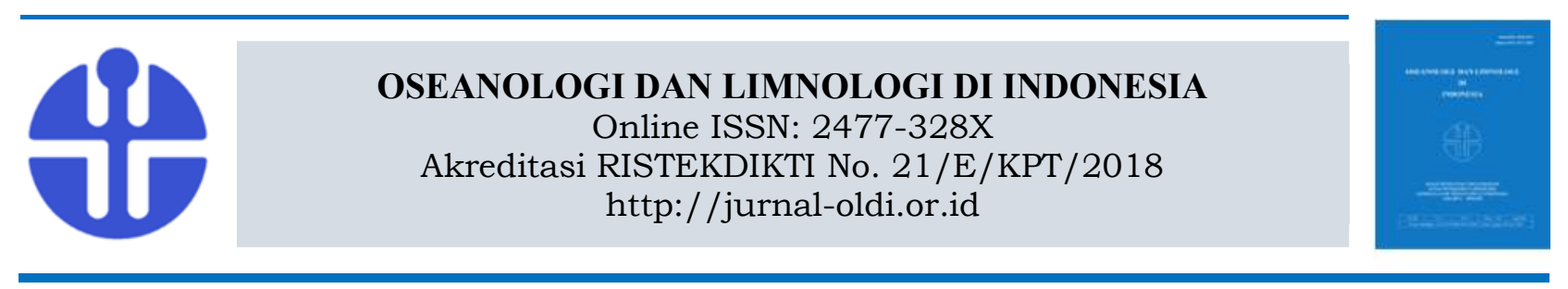

\title{
Struktur Komunitas Moluska di Padang Lamun Perairan Kepulauan Padaido dan Aimando Kabupaten Biak Numfor, Papua
}

\author{
Ludi Parwadani Aji ${ }^{1}$, Andriani Widyastuti ${ }^{1}$ dan Agustin Capriati ${ }^{1}$ \\ Loka Konservasi Biota Laut Biak - LIPI, Papua \\ Email: ludi_bio@yahoo.co.id
}

Submitted 31 January 2018. Reviewed 3 July 2018. Accepted 5 November 2018

DOI: 10.14203/oldi.2018.v3i3.184

\begin{abstract}
Abstrak
Moluska merupakan salah satu biota laut yang paling banyak ditemukan di daerah padang lamun dan dimanfaatkan oleh masyarakat di Biak. Akan tetapi informasi mengenai keanekaragaman spesies dan kelimpahan moluska di perairan Kepulauan Padaido dan Aimando, Biak Papua hingga saat ini masih kurang. Penelitian biota moluska di daerah padang lamun Kepulauan Padaido Aimando, Biak telah dilakukan pada bulan April - Oktober 2014. Metode sampling menggunakan transek kuadrat mulai dari tepi pantai menuju ke arah laut pada 15 stasiun. Sampel moluska diawetkan dalam larutan alkohol 40\% dan selanjutnya dibersihkan serta diidentifikasi di laboratorium. Diperoleh 239 spesies moluska yang terdiri dari 177 spesies dari kelas Gastropoda dan 62 spesies dari kelas Bivalvia. Moluska dengan penyebaran yang luas ditemukan pada spesies Monetaria annulus, Conomurex luhuanus dan Canarium urceus dari kelas Gastropoda, sedangkan dari kelas Bivalvia adalah Anadara antiquata. Nilai indeks keanekaragaman spesies $(\mathrm{H})$ tertinggi terdapat di Stasiun 7 $(3,951)$ dan terendah pada Stasiun 14 (3,077). Nilai indeks kekayaan spesies (d) berkisar antara 9,041-10,883 dan nilai indeks kemerataan spesies (J) berkisar antara 0,768 - 0,99. Adapun indeks dominan berkisar antara $0,020-0,092$. Dilihat dari indeks similaritasnya, Stasiun 3 memiliki kesamaan yang tinggi dengan Stasiun 4 . Penelitian ini dapat dijadikan sebagai sumber informasi keanekaragaman spesies dan kelimpahan moluska yang diperlukan dalam proses pengambilan keputusan untuk manajemen sumberdaya moluska di Biak.
\end{abstract}

Kata Kunci: struktur komunitas, gastropoda, bivalvia, Padaido, Aimando

\section{Abstract}

Community Structure of Mollusca in Seagrass Beds Padaido and Aimando Islands Biak Numfor Regency, Papua. Mollusca is one of marine biota which is commonly found in seagrass beds and largely utilized by inhabitants in Biak. However, information about the diversity and abundance of mollusca in Padaido Aimando Islands, Biak Papua is still limited. The research about mollusca composition in the seagrass beds of Padaido Aimando Islands, Biak was conducted in April - October 2014. Sampling method using quadrat transect from the beach toward the sea at 15 stations. Mollusca samples preserved in alcohol $40 \%$, then it was cleaned and identified in the laboratory. In this research was found 239 species of mollusca, which consists of 177 species from Gastropods and 62 species from Bivalves. Mollusks gastropod that have high distribution is Monetaria annulus, Conomurex luhuanus dan Canarium urceus, while of class Bivalvia is Anadara antiquata. The highest value index of species diversity $(\mathrm{H})$ is found at Station 7 (3.951) and the lowest at Station 14 (3.077). Value index of species richness (d) ranged between 9.041 and 10.883 and evenness index value $(\mathrm{J})$ ranged between 0.768 and 0.99 . While the dominancy index ranged from 0.020 to 0.092 . Based on similarity index, Station 3 has a high similarity with station 4 . This research provides valuable information on 
Aji et al.

the diversity and abundance of mollusca which can be useful for decision making aimed at the management of mollusca resource in Biak.

Keywords: community structure, gastropod, bivalve, Padaido, Aimando

\section{Pendahuluan}

Biak Numfor merupakan salah satu kabupaten kepulauan di Propinsi Papua yang terletak di bagian utara daratan besar Pulau Papua dan secara geografis terletak pada posisi $134^{\circ} 47^{\prime}-$ $136^{\circ} 48^{\prime}$ BT dan $0^{\circ} 21^{\prime}-1^{\circ} 31^{\prime}$ LS. Kabupaten ini berbatasan dengan Samudera Pasifik di sebelah utara dan timur, di sebelah barat berbatasan dengan Kabupaten Supiori dan di sebelah selatan dengan Selat Yapen. Kabupaten Biak Numfor terdiri dari kurang lebih 30 pulau-pulau kecil yang dikelilingi oleh terumbu karang. Beberapa gabungan dari pulau-pulau kecil tersebut adalah Kepulauan Padaido dan Aimando yang termasuk ke dalam wilayah distrik Padaido dan distrik Aimando.

Beberapa pulau memiliki pesisir dan laut yang sangat indah, dimana terdapat pulau yang berpenghuni dan yang tidak berpenghuni. Pulau yang tidak berpenghuni biasanya merupakan tempat untuk singgah sementara ketika para nelayan mencari ikan. Beberapa pulau yang terdapat di kepulauan Padaido dan Aimando merupakan bagian dari daerah perlindungan laut ataupun daerah pemanfaatan sumber daya laut dan banyak terdapat hamparan lamun. Padang lamun merupakan hamparan vegetasi yang luas dengan komponen penyusun utama tumbuhan lamun dan memiliki peran penting dalam menyusun ekosistem perairan laut. Salah satu kekayaan sumber daya laut yang banyak dijumpai adalah moluska seperti siput, kerang, gurita, sontong dan cumi-cumi. Moluska ini banyak ditemukan di daerah pesisir dengan padang lamun sebagai habitatnya (Urra et al. 2013).

Kelompok moluska yang ada di perairan ini merupakan salah satu tangkapan masyarakat untuk menopang perekonomian keluarga karena dijual untuk dikonsumsi oleh penduduk setempat. Pencarian moluska ini banyak dilakukan oleh ibuibu di wilayah pesisir pada saat air surut. Moluska dari kelompok siput dan kerang banyak ditangkap nelayan apabila kondisi perairan kurang mendukung untuk melaut mencari ikan. Adanya penangkapan yang berlebihan dalam semua ukuran siput dapat mengakibatkan turunnya jumlah biota moluska (Widyastuti dan Aji, 2016). Oleh karena itu, sumber daya moluska yang begitu besar perlu diungkap untuk memperoleh gambaran mengenai potensi dan sebaran dari spesies moluska yang ada di Perairan Padaido dan Aimando, sehingga dapat digunakan untuk pengembangan, pengelolaan dan pemanfaatannya yang lestari. Keanekaragaman spesies moluska di perairan Kepulauan Padaido dan Aimando perlu dikaji/diteliti karena masih minimnya informasi yang tersedia.

Tujuan dari penelitian ini adalah untuk mengetahui kondisi komunitas dan keanekaragaman spesies moluska dari kelas gastropoda (siput) dan bivalvia (kerang) yang terdapat di Perairan Padaido dan Aimando, Kabupaten Biak Numfor, Papua.

\section{Metodologi}

Penelitian dilaksanakan pada bulan April Oktober 2014 di 15 stasiun yang terletak di pesisir Kepulauan Padaido dan Aimando, Kabupaten Biak Numfor yaitu Pulau Nusi (Stasiun 1, 2), Wundi (Stasiun 3, 4), Auki (Stasiun 5, 6), Pai (Stasiun 7), Dawi (Stasiun 8, 9), Miosmangguandi (Stasiun 10, 11), Nukori (Stasiun 12,13) dan Padaidori (Stasiun 14, 15) (Gambar 1).

Sampling dilakukan dengan menggunakan transek kuadrat tegak lurus dari garis pantai dari posisi titik surut terendah ke arah laut sepanjang 200 meter untuk menyamakan ukuran sampling area pada setiap stasiun. Plot pengamatan yang digunakan adalah frame berukuran $50 \times 50 \mathrm{~cm}$. Adapun spesies dan tutupan lamun serta tipe substrat yang terdapat disekitar lokasi penelitian juga dicatat. Titik plot pengamatan dilakukan pada setiap jarak 10 meter sepanjang garis transek dengan pengamatan dilaksanakan pada saat kondisi air surut. Fauna moluska yang terdapat dalam frame diambil sampai kedalaman $20 \mathrm{~cm}$ dengan menggunakan sekop dan kemudian disaring dengan ayakan bermata jaring ukuran $0,5 \mathrm{~cm}$. Selain itu moluska yang ditemukan di sekitar area transek juga dicatat untuk menambah data spesies yang ditemukan. Sampel gastropoda dan bivalvia yang tersaring selanjutnya diawetkan dengan larutan alkohol 40\% dan kemudian diidentifikasi sampai ke tingkat spesies berdasarkan kunci identifikasi Abbott dan Dance (1990), Wilson (1993), Dharma (2005), Huber (2010), Tucker dan Tenorio (2013) dan Poppe et al. (2014). Identifikasi spesimen moluska dilakukan di Laboratorium UPT Loka Konservasi Biota Laut Biak - LIPI 


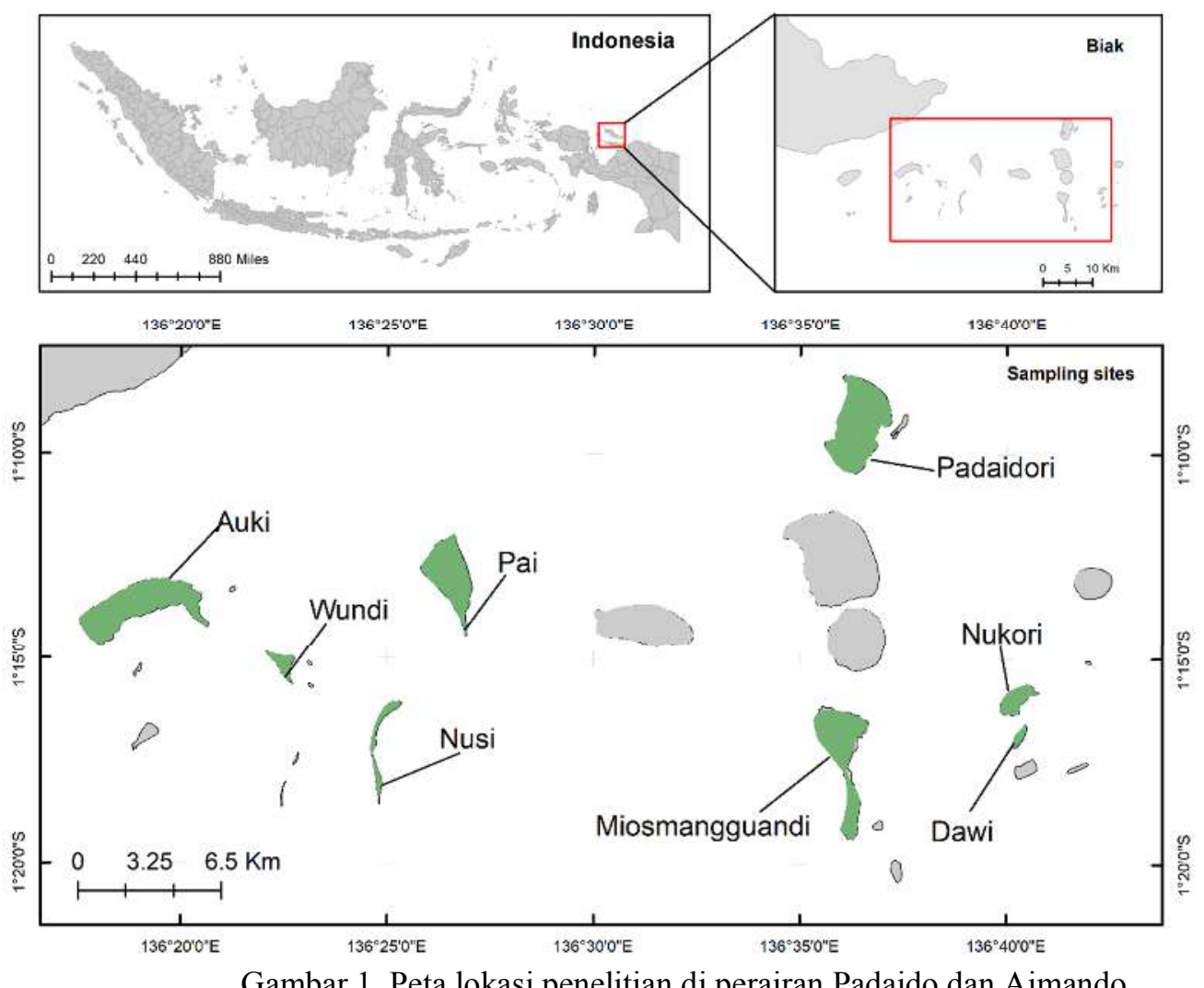

Gambar 1. Peta lokasi penelitian di perairan Padaido dan Aimando.

Figure 1. Study sites at Padaido and Aimando waters.

Indeks struktur komunitas yang dihitung adalah indeks keanekaragaman spesies (Shannon index of diversity), indeks dominasi spesies (Simpson index), kekayaan spesies, keseragaman spesies (Evennes index), selain itu kepadatan setiap spesies per stasiun juga dihitung. Selanjutnya, analisis kluster dilakukan dengan mentransformasikan data kelimpahan ke akar pangkat dua dahulu sebelum didapatkan kemiripan antarstasiun pengamatan. Penghitungan dilakukan dengan menggunakan software PRIMER 7. Berikut rumus beberapa indeks keanekaragaman yang dihitung.

Indeks keanekaragaman $=$

$$
H=\sum_{i=1}^{S} p i \ln p i
$$

$\mathrm{H}$ : indeks keanekaragaman spesies (Shannon index of diversity)

s: jumlah spesies dalam komunitas

pi: proporsi dari S yang terbentuk dari spesies ke $i$

Indeks kemerataan $=$

$$
\mathrm{E}=\frac{H^{\prime}}{H^{\prime} \max }
$$

$$
H \max =-\sum_{i=1}^{S} \frac{1}{S} \ln \frac{1}{S}=\ln S
$$

E: indeks kemerataan spesies (Pielou's Evenness Index)

$\mathrm{H}^{\prime}$ : nilai yang didapat dari Indeks keanekaragaman H'max: nilai maksimal dari indeks keanekaragaman

Indeks dominansi $=$

$$
D=\frac{\sum n(n-1)}{N(N-1)}
$$

D: indeks dominansi (Simpson's diversity index) $\mathrm{n}$ : jumlah total organisme pada spesies tertentu $\mathrm{N}$ : jumlah total organisme pada seluruh spesies

Indeks kekayaan spesies $=$

$$
D M g=\frac{(S-1)}{\ln N}
$$

$\mathrm{DM}_{\mathrm{g}}$ : Margalef's diversity index / Species richness index (d)

S: jumlah spesies

$\mathrm{N}$ : jumlah individu pada sampel 


\section{Hasil}

\section{Karakteristik Habitat}

Dari hasil pengamatan pada lokasi penelitian kepulauan Padaido Aimando ditemukan delapan spesies lamun yaitu Thalassia hemprichii (Th), Enhalus acoroides (Ea), Cymodocea rotundata (Cr), Cymodocea serrulata (Cs), Syringodium isoetifolium (Si), Halodule pinifolia (Hp), Halophila ovalis (Ho) dan Halodule uninervis $(\mathrm{Hu})$. Adapun tipe substrat pada setiap stasiun didominasi oleh pasir baik halus maupun kasar, rubble juga mendominasi kecuali pada Stasiun 11 hingga Stasiun 15. Ditinjau dari frekuensi kehadiran lamun di seluruh stasiun pengamatan dapat diketahui bahwa Thalassia hemprichii memiliki frekuensi kehadiran tertinggi (100\%) disusul oleh Cymodocea rotundata yang ditemukan pada 12 stasiun. Sedangkan frekuensi kehadiran lamun yang rendah adalah spesies Halodule uninervis dan Halodule pinifolia yang hanya ditemukan di tiga stasiun. Selanjutnya, spesies lamun terbanyak ditemukan pada stasiun 7 dengan enam spesies lamun dan terendah pada stasiun 9 dengan hanya ditemukan satu spesies lamun (Tabel 1). Komunitas lamun yang terdapat pada lokasi penelitian sebagian besar tergolong dalam tipe campuran (heterospesifik) dan hanya satu stasiun yaitu stasiun 9 yang tergolong dalam tipe monospesifik atau komunitas tunggal.

Persentase tutupan lamun di perairan Kepulauan Padaido Aimando yang terendah terdapat pada stasiun 9 dan 11 yaitu $20 \%$ sedangkan tutupan tertinggi terdapat pada stasiun 7 dengan $73 \%$. Adapun rata-rata tutupan lamun dari seluruh stasiun pengamatan adalah $41,7 \%$. Oleh karena itu dapat disimpulkan bahwa status padang lamun di daerah penelitian perairan Padaido Aimando menurut KEPMEN LH No. 200 Tahun 2004 tergolong dalam kondisi kurang kaya/ kurang sehat dengan prosentase penutupan berkisar antara $30-59,9 \%$. Selanjutnya tipe substrat yang ditemukan pada seluruh stasiun pengamatan adalah pasir halus, pasir kasar, pasir berlumpur, lumpur berpasir, rubble/patahan karang dan Halimeda mati. Berdasarkan analisis kemiripan antarstasiun dilihat dari spesies lamun dan tipe substratnya maka dapat dilihat bahwa stasiun penelitian terbagi menjadi tiga kluster utama (Gambar 2). Stasiun 1 dan 2 serta Stasiun 10 dan 11 memiliki kemiripan habitat yang tinggi, sedangkan Stasiun 9 dan 4 memiliki perbedaan lebih tinggi dibandingkan dengan stasiun lainnya.

Berdasarkan hasil analisis hubungan antara jumlah spesies molsuka dan tutupan lamun (\%) bahwa semakin besar presentasi tutupan lamun, moluska yang ditemukan spesiesnya semakin 222 banyak dan sebaliknya (Gambar 3 dan 4). Pada stasiun 7 memiliki jumlah spesies moluska yang cukup tinggi yaitu 54 spesies dan tutupan yang tinggi yakni $73 \%$ (Tabel 2). Begitu juga dengan stasiun 1, 2, 3 dan 10 dimana jumlah jenis di masing-masing stasiun berurutan adalah 49, 51, 42 dan 45 jenis. Adapun pada stasiun 14, walaupun hanya terdapat dua jenis lamun dengan tutupan $44 \%$, ditemukan gastropoda jenis Cerithium zonatum dengan jumlah individu sangat tinggi yaitu 44 individu.

\section{Komposisi Moluska}

Hasil penelitian yang telah dilakukan di 15 stasiun didapatkan total 1137 individu moluska yang termasuk kedalam 139 spesies. Sebanyak 984 individu $(86,5 \%)$ terdiri dari 177 spesies $(74 \%)$ dari kelas gastropoda dan 153 individu (13,5\%) terdiri dari 62 spesies (26\%) dari kelas bivalvia. Jumlah individu dan spesies moluska terbanyak ditemukan pada Stasiun 14 dengan 191 individu $(16,8 \%)$ terdiri dari 55 spesies atau sekitar 8,2\% dari seluruh spesies gastropoda dan bivalvia yang ditemukan di daerah penelitian. Stasiun 15 dengan 133 individu $(11,7 \%)$ yang terdiri dari 51 spesies moluska gastropoda dan bivalvia merupakan jumlah spesies terbanyak kedua setelah stasiun 14 . Selanjutnya pada stasiun 12 ditemukan jumlah individu dan spesies terendah dengan jumlah 41 individu $(3,6 \%)$ terdiri dari 35 spesies $(5,2 \%)$ dari seluruh individu dan spesies yang ditemukan pada lokasi penelitian.

Komposisi spesies dan jumlah individu moluska gastropoda dan bivalvia yang ditemukan serta sebarannya disajikan dalam Tabel 2.

Jenis gastropoda dari famili Nassariidae memiliki spesies terbanyak yakni 19 spesies yang diikuti oleh Cerithidae (18 spesies) (Gambar 4), sedangkan untuk bivalvia famili tertinggi adalah Veneriidae (15 spesies) (Gambar 5). Jika dilihat dari perbandingan antara gastropoda dan bivalvia, gastropoda memiliki jumlah atau kepadatan yang lebih tinggi daripada bivalvia dengan kepadatan rata-rata permeter persegi yakni 15,16 individu. Kepadatan gastropoda lebih besar (13,12 individu $/ \mathrm{m}^{2}$ ) bila dibandingkan dengan bivalvia $\left(2,04 \mathrm{individu} / \mathrm{m}^{2}\right)$. Kepadatan tertinggi gastropoda ditemukan pada stasiun 14 (37,2 individu/ $\left.\mathrm{m}^{2}\right)$, sedangkan bivalvia terdapat pada stasiun 2 dan 6 (3 individu $\left./ \mathrm{m}^{2}\right)($ Gambar 6).

Sebaran gastropoda yang tertinggi yaitu dari spesies Monetaria annulus dan Conomurex luhuanus. Kedua spesies ini ditemukan di setiap stasiun penelitian. Sedangkan jumlah individu moluska gastropoda tertinggi adalah Cerithium zonatum yang sangat melimpah yaitu di Pulau Padaidori Aimando pada stasiun 14 (sebanyak 44 
Oseanologi dan Limnologi di Indonesia 2018 3(3):219-234

individu) dan 15 (sebanyak 16 individu). Di stasiun 1 dan 6 kelimpahan C. zonatum sangat sedikit yaitu hanya 1 individu dan pada stasiun lainnya tidak ditemukan. Adapun sebaran moluska bivalvia yang terluas adalah Anadara antiquata yang ditemukan di 12 stasiun dari total 15 stasiun (Gambar 7).

Tabel 1. Kondisi daerah penelitian di 15 stasiun.

Table 1. Condition of research site in 15 sampling sites.

\begin{tabular}{lllll}
\hline Station & Island & Species & $\begin{array}{l}\text { Coverage } \\
\text { of } \\
\text { seagrass } \\
(\%)\end{array}$ & Substrat type \\
\hline 1 & Nusi & Th, Ea, Hp, Cr & 47 & fine sand, rubble \\
2 & Nusi & Th, Ea, Hp, Cr, Cs & 58 & fine sand, rubble \\
3 & Wundi & Th, Cr, Ho, Si, Ea & 42 & fine sand, coarse sand, rubble \\
4 & Wundi & Th, Cr & 40 & fine sand, coarse sand, rubble \\
5 & Auki & Th, Cr, Ea, Hp, Ho & 27 & fine sand, rubble \\
6 & Auki & Th, Cr, Ea & 40 & fine sand, rubble \\
7 & Pai & Th, Ea, Cr, Si, Cs, & 73 & sandy mud \\
& & $\mathrm{Hu}$ & & \\
8 & Dawi & Th, Cr, Ea & 37 & rubble (reef flat) \\
9 & Dawi & Th & 20 & coarse sand (reef flat) \\
10 & Miosmangguandi & Th, $\mathrm{Hu}, \mathrm{Ho}, \mathrm{Cr}, \mathrm{Si}$ & 50 & coarse sand, rubble \\
11 & Miosmangguandi & Th, Hu, Ho & 20 & coarse sand, rubble \\
12 & Nukori & $\mathrm{Th}, \mathrm{Cr}, \mathrm{Cs}, \mathrm{Ho}$ & 40 & muddy sand \\
13 & Nukori & $\mathrm{Th}, \mathrm{Ho}, \mathrm{Cr}, \mathrm{Cs}$ & 22 & coarse sand \\
14 & Padaidori & $\mathrm{Th}, \mathrm{Ea}$ & 44 & coarse sand, dead halimeda \\
15 & Padaidori & $\mathrm{Th}, \mathrm{Cr}, \mathrm{Si}$ & 65 & muddy sand \\
\cline { 2 - 4 }
\end{tabular}

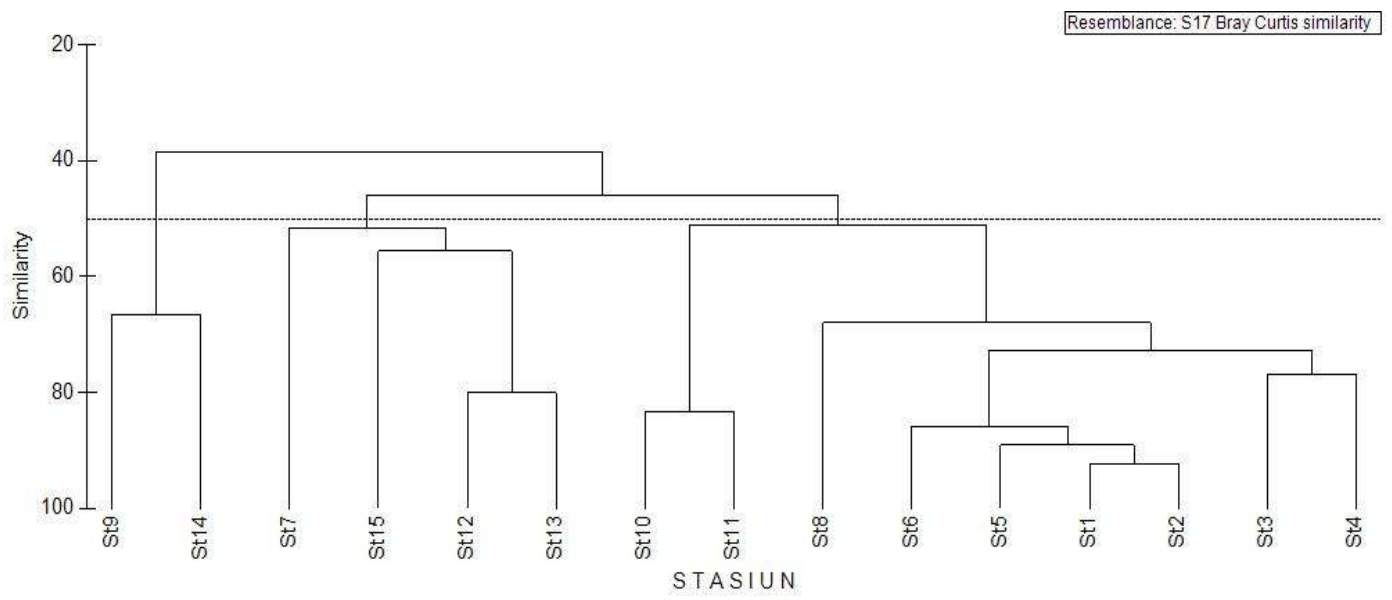

Gambar 2. Kemiripan stasiun berdasarkan spesies lamun dan tipe substratnya.

Figure 2. Stations similarity according to seagrass species and substrat type. 
Aji et al.



Gambar 3. Jumlah spesies lamun, tutupan lamun, jumlah spesies moluska dan jumlah individu moluska pada setiap stasiun.

Figure 3. Seagrass species, seagrass coverage, the number of mollusca species and mollusca individu in each sampling site.

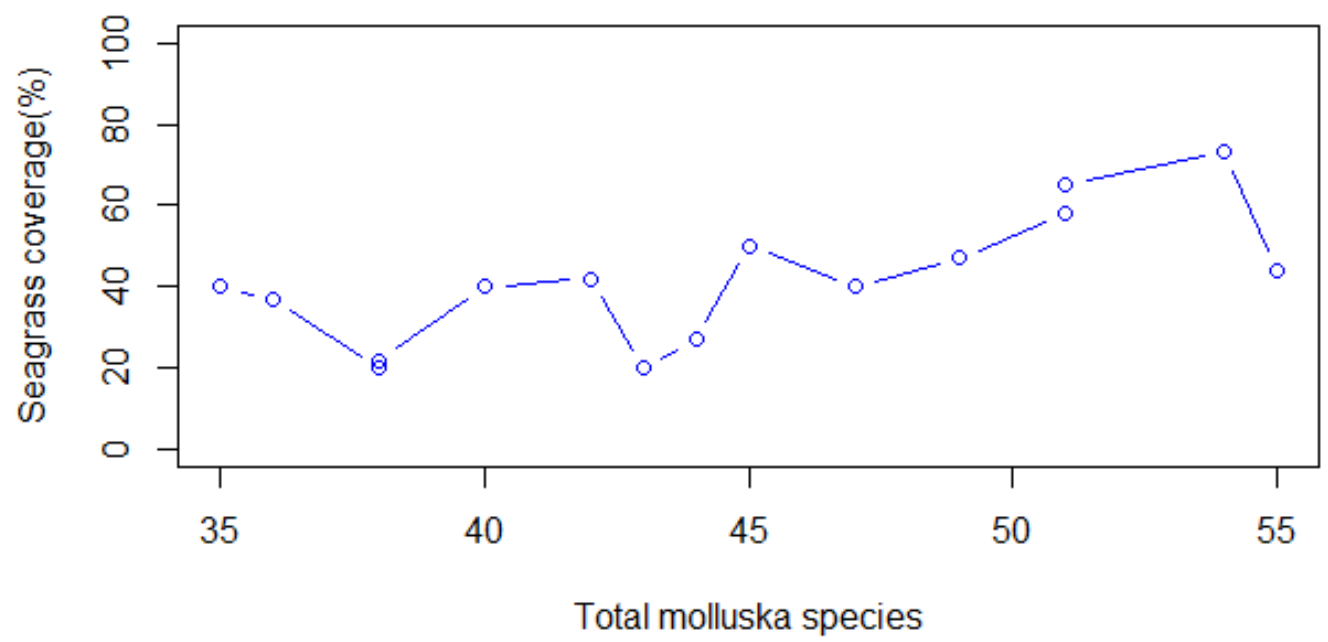

Gambar 4. Korelasi antara jumlah spesies moluska dan persentase tutupan lamun. Figure 4. Correlation between total molluska species and percent coverage of seagrass. 
Oseanologi dan Limnologi di Indonesia 2018 3(3):219-234

Tabel 2. Komposisi spesies pada 15 stasiun penelitian.

Table 2. Species composition in 15 research sampling sites.

\begin{tabular}{|c|c|c|c|c|c|c|c|}
\hline No & Family & Species & $\begin{array}{l}\text { Tot } \\
\text { Ind. }\end{array}$ & No & Family & Species & $\begin{array}{l}\text { Tot } \\
\text { Ind. }\end{array}$ \\
\hline 1 & Acteonidae & Pupa sulcata & 1 & 121 & Naticidae & \begin{tabular}{|l|} 
Polinices \\
aurantius
\end{tabular} & 5 \\
\hline 2 & Angariidae & $\begin{array}{l}\text { Angaria } \\
\text { delphinus }\end{array}$ & 2 & 122 & Naticidae & P. cf. albumen & 1 \\
\hline 3 & Architectonicidae & Psilaxis radiatus & 3 & 123 & Naticidae & $\begin{array}{l}\text { P.cf. } \\
\text { mikawaensis }\end{array}$ & 2 \\
\hline 4 & Buccinidae & $\begin{array}{l}\text { Cantharus cf. } \\
\text { fumosus }\end{array}$ & 2 & 124 & Naticidae & P. flemingianus & 3 \\
\hline 5 & Buccinidae & C. cf. pulchra & 1 & 125 & Naticidae & P. mammilla & 8 \\
\hline 6 & Buccinidae & Engina alveolata & 3 & 126 & Naticidae & P. melanostomus & 4 \\
\hline 7 & Buccinidae & E. mendicaria & 2 & 127 & Naticidae & P. peselephanti & 4 \\
\hline 8 & Buccinidae & E. zonalis & 11 & 128 & Neritidae & Smaragdia sp. & 4 \\
\hline 9 & Buccinidae & $\begin{array}{l}\text { Euthria cf. } \\
\text { javanica }\end{array}$ & 2 & 129 & Olividae & Oliva amethystina & 2 \\
\hline 10 & Buccinidae & $\begin{array}{l}\text { Prodotia cf. } \\
\text { iostomus }\end{array}$ & 1 & 130 & Olividae & O. cf. elegans & 1 \\
\hline 11 & Bullidae & Bulla ampulla & 1 & 131 & Olividae & O. carneola & 1 \\
\hline 12 & Bullidae & B. vernicosa & 1 & 132 & Olividae & O. tesselata & 19 \\
\hline 13 & Bursidae & $\begin{array}{l}\text { Bursa } \\
\text { tuberosissima }\end{array}$ & 1 & 133 & Ranellidae & $\begin{array}{l}\text { Cymatium } \\
\text { lotorium }\end{array}$ & 1 \\
\hline 14 & Cassidae & Cassis cornuta & 1 & 134 & Ranellidae & C.pfeifferianum & 1 \\
\hline 15 & Cerithidae & Aluco aluco & 11 & 135 & Ranellidae & C. nicobaricum & 1 \\
\hline 16 & Cerithidae & $\begin{array}{l}\text { Cerithium cf. } \\
\text { alveolum }\end{array}$ & 17 & 136 & Seraphsidae & \begin{tabular}{|l|} 
Terebellum \\
terebellum \\
\end{tabular} & 2 \\
\hline 17 & Cerithiidae & C. cf. torresi & 1 & 137 & Phasianellidae & $\begin{array}{l}\text { Phasianella } \\
\text { rubens }\end{array}$ & 21 \\
\hline 18 & Cerithiidae & C. citrinum & 19 & 138 & Phasianellidae & P. variegata & 41 \\
\hline 19 & Cerithiidae & C. corallium & 1 & 139 & Phasianellidae & P. ventricosa & 1 \\
\hline 20 & Cerithiidae & C. columnum & 2 & 140 & Siliquariidae & Tenagodus sp. & 4 \\
\hline 21 & Cerithiidae & C. kobelti & 2 & 141 & Strombidae & \begin{tabular}{|l} 
Canarium \\
labiatus
\end{tabular} & 17 \\
\hline 22 & Cerithiidae & C. salebrosum & 13 & 142 & Strombidae & C. mutabilis & 14 \\
\hline 23 & Cerithiidae & C. tenellum & 2 & 143 & Strombidae & C. urceus & 25 \\
\hline 24 & Cerithiidae & C. nodulosum & 4 & 144 & Strombidae & C. microurceus & 3 \\
\hline 25 & Cerithiidae & C. zonatum & 62 & 145 & Strombidae & $\begin{array}{l}\text { Conomurex } \\
\text { luhuanus }\end{array}$ & 22 \\
\hline 26 & Cerithiidae & $\begin{array}{l}\text { Clypeomorus } \\
\text { petrosa }\end{array}$ & 3 & 146 & Strombidae & \begin{tabular}{|l}
$\begin{array}{l}\text { Gibberulus } \\
\text { gibbosus }\end{array}$ \\
\end{tabular} & 45 \\
\hline 27 & Cerithiidae & C. zonata & 11 & 147 & Strombidae & $\begin{array}{l}\text { Harpago } \\
\text { chiragra }\end{array}$ & 6 \\
\hline 28 & Cerithiidae & C. cf. bifasciata & 34 & 148 & Strombidae & Lambis lambis & 7 \\
\hline 29 & Cerithiidae & $\begin{array}{l}\text { Rhinoclavis } \\
\text { aspera }\end{array}$ & 8 & 149 & Strombidae & L. millepeda & 4 \\
\hline 30 & Cerithiidae & R. cf. fasciata & 1 & 150 & Strombidae & L. scorpius & 1 \\
\hline 31 & Cerithiidae & $R$. sinensis & 1 & 151 & Strombidae & $\begin{array}{l}\text { Lentigo } \\
\text { lentiginosus }\end{array}$ & 15 \\
\hline 32 & Cerithiidae & R. vertagus & 18 & 152 & Terebridae & $\begin{array}{l}\text { Diplomeriza } \\
\text { duplicata }\end{array}$ & 1 \\
\hline 33 & Columbellidae & Atilia scripta & 54 & 153 & Terebridae & Myurella affinis & 1 \\
\hline 34 & Columbellidae & A. ocellata & 1 & 154 & Terebridae & $\begin{array}{l}\text { Oxymeris } \\
\text { areolata }\end{array}$ & 1 \\
\hline
\end{tabular}


Aji et al.

\begin{tabular}{|c|c|c|c|c|c|c|c|}
\hline No & Family & Species & $\begin{array}{l}\text { Tot } \\
\text { Ind. }\end{array}$ & No & Family & Species & $\begin{array}{l}\text { Tot } \\
\text { Ind. }\end{array}$ \\
\hline 35 & Columbellidae & A. testudinaria & 10 & 155 & Terebridae & O. maculata & 1 \\
\hline 36 & Columbellidae & Euplica scripta & 5 & 156 & Terebridae & Terebra affinis & 3 \\
\hline 37 & Columbellidae & E. varians & 1 & 157 & Terebridae & T. subulata & 2 \\
\hline 38 & Columbellidae & Mitrella puella & 1 & 158 & Trochidae & $\begin{array}{l}\text { Clanculus } \\
\text { atropurpureus }\end{array}$ & 9 \\
\hline 39 & Columbellidae & Pyrene versicolor & 5 & 159 & Trochidae & $\begin{array}{l}\text { Ethalia cf. } \\
\text { guamensis }\end{array}$ & 1 \\
\hline 40 & Conidae & Conus arenatus & 4 & 160 & Trochidae & $\begin{array}{l}\text { Stomatia } \\
\text { phymotis }\end{array}$ & 1 \\
\hline 41 & Conidae & C. aurisiacus & 1 & 161 & Trochidae & Tectus fenestratus & 5 \\
\hline 42 & Conidae & C. capitaneus & 1 & 162 & Trochidae & T. piramis & 1 \\
\hline 43 & Conidae & C. coronatus & 12 & 163 & Trochidae & $\begin{array}{l}\text { Trochus cf. } \\
\text { aemulans }\end{array}$ & 3 \\
\hline 44 & Conidae & C. cf. varius & 2 & 164 & Trochidae & T. niloticus & 8 \\
\hline 45 & Conidae & C. eburneus & 4 & 165 & Trochidae & T. radiatus & 2 \\
\hline 46 & Conidae & C. litteratus & 10 & 166 & Trochidae & T. maculatus & 3 \\
\hline 47 & Conidae & C. virgo & 15 & 167 & Turbinidae & $\begin{array}{l}\text { Angaria } \\
\text { delphinus }\end{array}$ & 2 \\
\hline 48 & Conidae & C. textile & 1 & 168 & Turbinidae & Astralium calcar & 1 \\
\hline 49 & Conidae & C. marmoreus & 5 & 169 & Turbinidae & Liotina peronii & 2 \\
\hline 50 & Conidae & C. miles & 1 & 170 & Turbinidae & Turbo petholatus & 1 \\
\hline 51 & Conidae & C. ebraeus & 3 & 171 & Turbinidae & T. chrysostomus & 1 \\
\hline 52 & Conidae & C. planorbis & 1 & 172 & Turridae & $\begin{array}{l}\text { Epidirona cf. } \\
\text { multiseriata }\end{array}$ & 1 \\
\hline 53 & Conidae & C. pulicarius & 2 & 173 & Turridae & Inquisitor $s p$. & 1 \\
\hline 54 & Conidae & $\begin{array}{l}\text { C. (cleobula) } \\
\text { quercinus }\end{array}$ & 1 & 174 & Turridae & Turricula sp. & 2 \\
\hline 55 & Conidae & C. stramineus & 1 & 175 & Turridae & $\begin{array}{l}\text { Turridrupa cf. } \\
\text { bijubata }\end{array}$ & 1 \\
\hline 56 & Conidae & C. sulcatus & 2 & 176 & Volutidae & $\begin{array}{l}\text { Cymbiola } \\
\text { vespertilio }\end{array}$ & 3 \\
\hline 57 & Coralliophilidae & Rapa incurva & 1 & 177 & Volutidae & Melo aethiopicus & 1 \\
\hline 58 & Coralliophilidae & $\begin{array}{l}\text { Coralliophila cf. } \\
\text { persica }\end{array}$ & 1 & 178 & Arcidae & $\begin{array}{l}\text { Anadara } \\
\text { antiquata }\end{array}$ & 14 \\
\hline 59 & Costellaridae & Pupa cf. sulcata & 1 & 179 & Arcidae & Barbatia sp. & 3 \\
\hline 60 & Costellaridae & $\begin{array}{l}\text { Vexillum } \\
\text { rugosum }\end{array}$ & 5 & 180 & Cardiidae & $\begin{array}{l}\text { Corculum } \\
\text { cardissa }\end{array}$ & 2 \\
\hline 61 & Costellaridae & V. exasperatum & 6 & 181 & Cardiidae & Fragum fragum & 7 \\
\hline 62 & Costellariidae & V. gruneri & 3 & 182 & Cardiidae & F. unedo & 5 \\
\hline 63 & Costellariidae & V. michaui & 2 & 183 & Cardiidae & $\begin{array}{l}\text { Maoricardium cf. } \\
\text { setosum }\end{array}$ & 1 \\
\hline 64 & Costellariidae & V. plicarium & 2 & 184 & Cardiidae & $\begin{array}{l}\text { Trachycardium } \\
\text { rugosum }\end{array}$ & 1 \\
\hline 65 & Costellariidae & V. virgo & 8 & 190 & Cardiidae & Vasticardium sp. & 1 \\
\hline 66 & Costellariidae & V. semifasciatum & 1 & 185 & Cardiidae & V.cf. papuanum & 1 \\
\hline 67 & Cymatiidae & Charonia tritonis & 1 & 186 & Cardiidae & V. elongatum & 5 \\
\hline 68 & Cypraeidae & Cypraea tigris & 9 & 187 & Cardiidae & $V$. flavum & 2 \\
\hline 69 & Cypraeidae & C. argus & 1 & 188 & Cardiidae & V. kengaluorum & 1 \\
\hline 70 & Cypraeidae & C. arabica & 1 & 189 & Cardiidae & V. pectiniforme & 1 \\
\hline 71 & Cypraeidae & Erronea errones & 2 & 191 & Chamidae & Chama sp. & 1 \\
\hline 72 & Cypraeidae & $\begin{array}{l}\text { Monetaria } \\
\text { annulus }\end{array}$ & 61 & 192 & Donacidae & Donax faba & 3 \\
\hline 73 & Cypraeidae & M. moneta & 22 & 193 & Donacidae & D. cf. deltoides & 1 \\
\hline
\end{tabular}


Oseanologi dan Limnologi di Indonesia 2018 3(3):219-234

\begin{tabular}{|c|c|c|c|}
\hline No & Family & Species & $\begin{array}{l}\text { Tot } \\
\text { Ind. }\end{array}$ \\
\hline 74 & Cypraeidae & M. caputserpentis & 3 \\
\hline 75 & Cypraeidae & $\begin{array}{l}\text { Mauritia } \\
\text { mauritiana }\end{array}$ & 1 \\
\hline 76 & Cypraeidae & $\begin{array}{l}\text { Palmadusta } \\
\text { clandestina }\end{array}$ & 1 \\
\hline 77 & Cypraeidae & $\begin{array}{l}\text { Chelycypraea } \\
\text { testudinaria }\end{array}$ & 1 \\
\hline 78 & Cypraeidae & Lyncina vitellus & 1 \\
\hline 79 & Fissurellidae & $\begin{array}{l}\text { Hemitoma } \\
\text { tricarinata }\end{array}$ & 1 \\
\hline 80 & Hamminoeidae & $\begin{array}{l}\text { Aliculastrum } \\
\text { cylindricus }\end{array}$ & 5 \\
\hline 81 & Hamminoeidae & Atys naucum & 4 \\
\hline 82 & Haliotidae & Haliotis asinina & 3 \\
\hline 83 & Mitridae & Mitra mitra & 5 \\
\hline 84 & Mitridae & $\begin{array}{l}\text { Scabricola cf. } \\
\text { ocellata }\end{array}$ & 1 \\
\hline 85 & Mitridae & $\begin{array}{l}\text { Imbricaria } \\
\text { conularis }\end{array}$ & 1 \\
\hline 86 & Mitridae & Mitra papalis & 2 \\
\hline 87 & Mitridae & M. cardinalis & 4 \\
\hline 88 & Mitridae & M. stictica & 2 \\
\hline 89 & Mitridae & M. chrysostoma & 1 \\
\hline 90 & Mitridae & $\begin{array}{l}\text { Pterygia } \\
\text { fenestrata }\end{array}$ & 1 \\
\hline 91 & Muricidae & Morula funiculus & 1 \\
\hline 92 & Muricidae & $\begin{array}{l}\text { Muricodrupa cf. } \\
\text { fiscella }\end{array}$ & 2 \\
\hline 93 & Nassariidae & Hebra corticata & 1 \\
\hline 94 & Nassariidae & H. subspinosa & 3 \\
\hline 95 & Nassariidae & $\begin{array}{l}\text { Nassarius } \\
\text { acuticostus }\end{array}$ & 7 \\
\hline 96 & Nassariidae & N. albescens & 24 \\
\hline 97 & Nassariidae & $N$. arcularius & 7 \\
\hline 98 & Nassariidae & N. cf. conoidalis & 3 \\
\hline 99 & Nassariidae & N. cf. castus & 1 \\
\hline 100 & Nassariidae & N. cf. crematus & 3 \\
\hline 101 & Nassariidae & N. cf. reeveanus & 1 \\
\hline 102 & Nassariidae & N. cf. sufflatus & 1 \\
\hline 103 & Nassariidae & N. globosus & 8 \\
\hline 104 & Nassariidae & N. glans & 1 \\
\hline 105 & Nassariidae & N. gruneri & 1 \\
\hline 106 & Nassariidae & N. luridus & 1 \\
\hline 107 & Nassariidae & N. limnaeformis & 2 \\
\hline 108 & Nassariidae & N. margaritiferus & 1 \\
\hline 109 & Nassariidae & N. semisulcatus & 2 \\
\hline
\end{tabular}

\begin{tabular}{|c|c|c|c|}
\hline No & Family & Species & $\begin{array}{l}\text { Tot } \\
\text { Ind. }\end{array}$ \\
\hline 194 & Fimbriidae & Fimbria fimbriata & 1 \\
\hline 195 & Glycimerididae & Glycymeris reevei & 1 \\
\hline 196 & Isognomonidae & $\begin{array}{l}\text { Isognomon } \\
\text { isognomon }\end{array}$ & 1 \\
\hline 197 & Mactridae & $\begin{array}{l}\text { Mactra } c f . \\
\text { grandis }\end{array}$ & 1 \\
\hline 198 & Mactridae & M. cf. incarnata & 1 \\
\hline 199 & Mactridae & M. maculata & 11 \\
\hline 200 & Malleidae & Malleus malleus & 1 \\
\hline 201 & Mesodesmatidae & $\begin{array}{l}\text { Atactodea } c f . \\
\text { striata }\end{array}$ & 1 \\
\hline 202 & Mytilidae & Brachidontes sp. & 3 \\
\hline 203 & Mytilidae & $\begin{array}{l}\text { Modiolus } \\
\text { proclivis }\end{array}$ & 1 \\
\hline 204 & Mytilidae & M. auriculatus & 2 \\
\hline 205 & Mytilidae & $\begin{array}{l}\text { Septifer } \\
\text { bilocularis }\end{array}$ & 1 \\
\hline 206 & Nuculanoidea & Nuculana sp. & 5 \\
\hline 207 & Periplomatiidae & Periploma sp. & 4 \\
\hline 208 & Pinnidae & Atrina vexillum & 1 \\
\hline 209 & Pinnidae & Pinna incurva & 3 \\
\hline 210 & Pinnidae & P. muricata & 2 \\
\hline 211 & Psammobiidae & Gari convexa & 1 \\
\hline 212 & Psammobiidae & G. cf. elongata & 1 \\
\hline 213 & Pteriidae & $\begin{array}{l}\text { Pinctada } \\
\text { margaritifera }\end{array}$ & 1 \\
\hline 214 & Pyramidellidae & Pyramidella acus & 3 \\
\hline 215 & Pyramidellidae & Milda ventricosa & 2 \\
\hline 216 & Semelidae & Semele sp. & 15 \\
\hline 217 & Spondilydae & $\begin{array}{l}\text { Spondylus } \\
\text { croceus }\end{array}$ & 1 \\
\hline 218 & Tridacnidae & $\begin{array}{l}\text { Hippopus } \\
\text { hippopus }\end{array}$ & 4 \\
\hline 219 & Tridacnidae & Tridacna crocea & 2 \\
\hline 220 & Tridacnidae & T. maxima & 1 \\
\hline 221 & Tridacnidae & T. squamosa & 2 \\
\hline 222 & Tellinidae & Tellina cf palatum & 3 \\
\hline 223 & Tellinidae & T. scobinata & 2 \\
\hline 224 & Tellinidae & T. virgata & 4 \\
\hline 225 & Veneridae & $\begin{array}{l}\text { Antigona } \\
\text { lamellaris }\end{array}$ & 1 \\
\hline 226 & Veneridae & Callista accincta & 1 \\
\hline 227 & Veneridae & Dosinia victoriae & 1 \\
\hline 228 & Veneridae & $\begin{array}{l}\text { Lioconcha } \\
\text { castrensis }\end{array}$ & 3 \\
\hline 229 & Veneridae & L. cf. annettae & 1 \\
\hline
\end{tabular}


Aji et al.

\begin{tabular}{|c|l|l|r|}
\hline No & \multicolumn{1}{|c|}{ Family } & \multicolumn{1}{|c|}{ Species } & $\begin{array}{r}\text { Tot } \\
\text { Ind. }\end{array}$ \\
\hline 110 & Nassariidae & N. pullus & 2 \\
\hline 111 & Nassariidae & N. venustus & 3 \\
\hline 112 & Naticidae & $\begin{array}{l}\text { Natica aff. } \\
\text { gualtieriana }\end{array}$ & 1 \\
\hline 113 & Naticidae & N. cf. euzona & 1 \\
\hline 114 & Naticidae & N. cf. luculenta & 1 \\
\hline 115 & Naticidae & N. cf. sertata & 1 \\
\hline 116 & Naticidae & N. fasciata & 9 \\
\hline 117 & Naticidae & N. onca & 1 \\
\hline 118 & Naticidae & N. zonalis & 1 \\
\hline 119 & Naticidae & N. tigrina & 1 \\
\hline 120 & Naticidae & N. vitellus & 1 \\
\hline
\end{tabular}

\begin{tabular}{|l|l|l|r|}
\hline No & \multicolumn{1}{|c|}{ Family } & \multicolumn{1}{|c|}{ Species } & $\begin{array}{r}\text { Tot } \\
\text { Ind. }\end{array}$ \\
\hline 230 & Veneridae & L. sowerbyi & 1 \\
\hline 231 & Veneridae & $\begin{array}{l}\text { Gafrarium } \\
\text { menkei }\end{array}$ & 1 \\
\hline 232 & Veneridae & G. pectinatum & 1 \\
\hline 233 & Veneridae & Meretrix sp. & 4 \\
\hline 234 & Veneridae & Pitar citrinus & 1 \\
\hline 235 & Veneridae & $\begin{array}{l}\text { P. (propitar) } \\
\text { obliquatus }\end{array}$ & 2 \\
\hline 236 & Veneridae & $\begin{array}{l}\text { Tawera } \\
\text { australiana }\end{array}$ & 1 \\
\hline 237 & Veneridae & Tapes sulcarius & 1 \\
\hline 238 & Veneridae & T. litteratus & 1 \\
\hline 239 & Veneridae & Timoclea marica & 2 \\
\hline
\end{tabular}

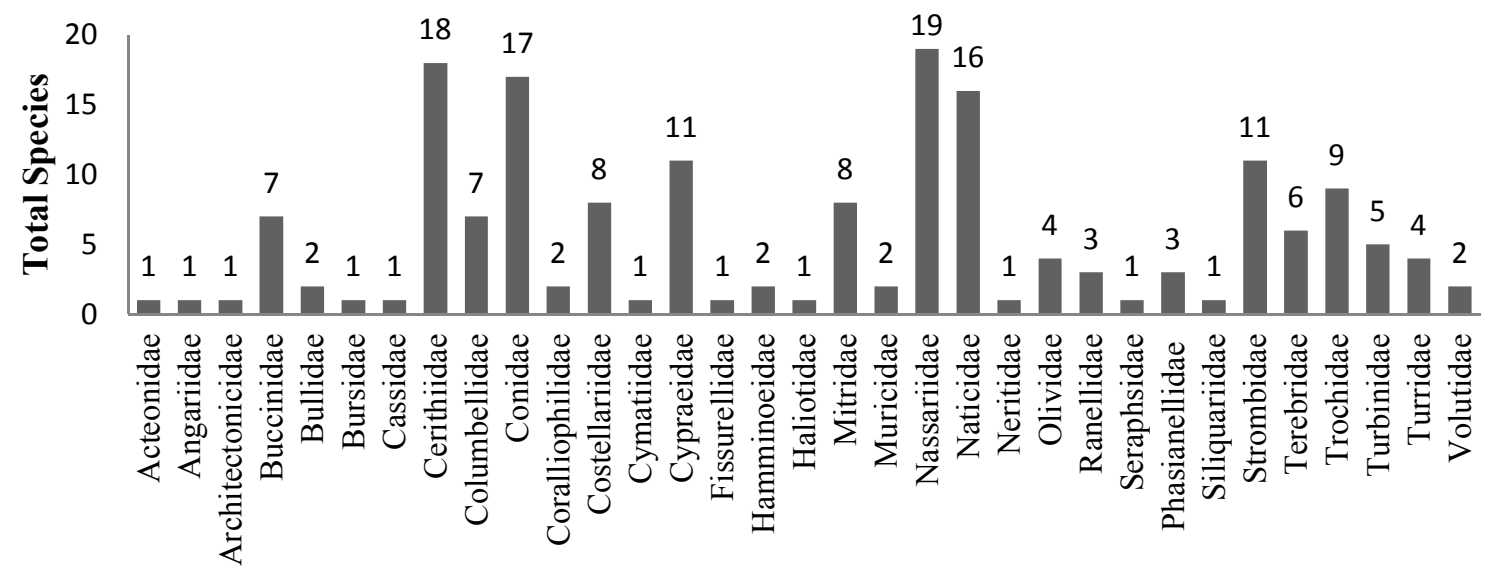

Family

Gambar 4. Jumlah spesies gastropoda pada setiap famili yang ditemukan.

Figure 4 . The number of gastropoda from each family during the research.

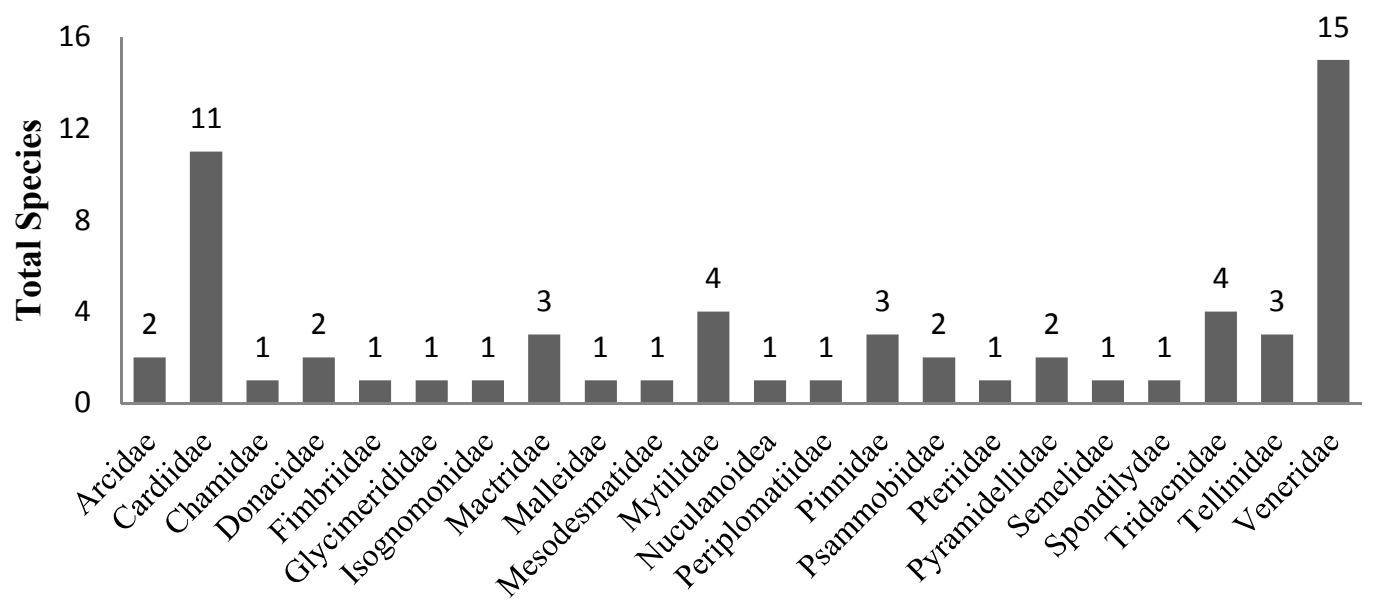

Family

Gambar 5. Jumlah spesies bivalvia pada setiap famili yang ditemukan.

Figure 5. The number of bivalvia from each family during the research. 


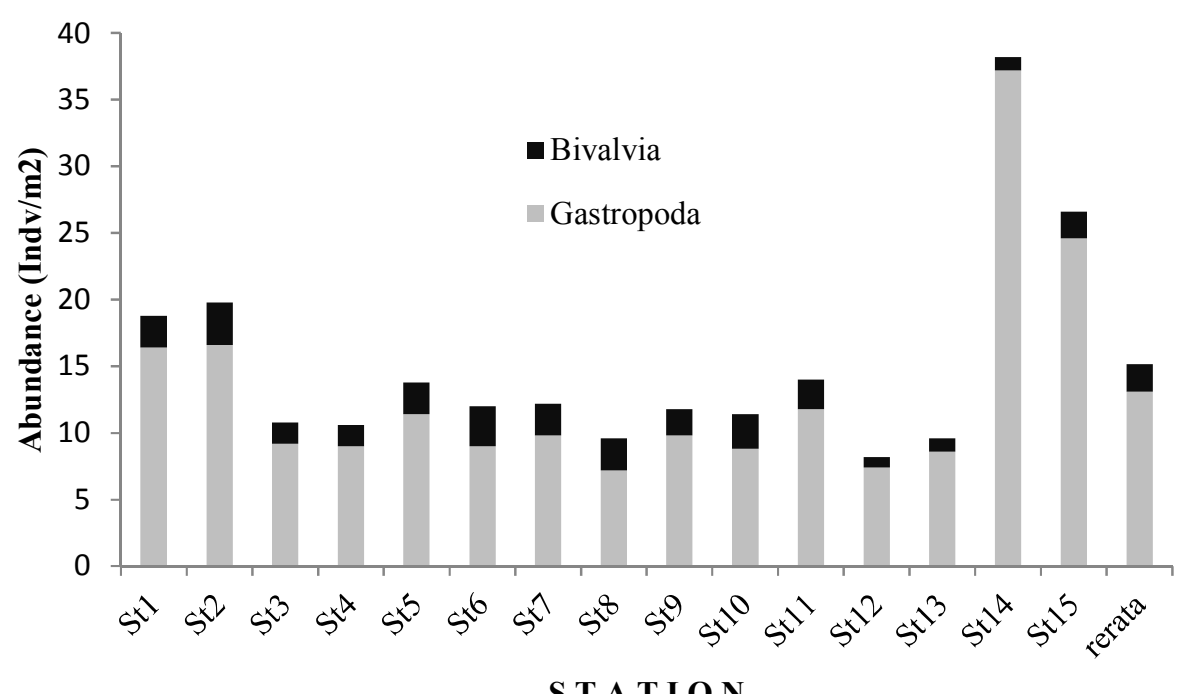

Gambar 6. Jumlah spesies dan kepadatan (individu $/ \mathrm{m}^{2}$ ) moluska di setiap stasiun.

Figure 6. The number of species and abundance (individu/ $\mathrm{m}^{2}$ ) mollusca in each sampling site.



Gambar 7. Sebaran dan kepadatan spesies moluska (Monetaria annulus, Conomurex luhuanus, Anadara antiquata dan Cerithium zonatum) pada setiap stasiun. Bulatan besar pada stasiun menunjukan kehadiran dan kepadatan moluska. Lingkaran yang menghubungkan setiap stasiun menunjukan kesamaan antar stasiun berdasarkan spesies dan kelimpahan moluska (Monetaria annulus, Conomurex luhuanus, Anadara antiquata dan Cerithium zonatum).

Figure 7. Distribution and abundance of mollusca species (Monetaria annulus, Conomurex luhuanus, Anadara antiquata dan Cerithium zonatum) from each station. Big circle on station indicates of present and abundance of mollusca. Circle that connect every station show the similarity between stations according to species and abundance of mollusca (Monetaria annulus, Conomurex luhuanus, Anadara antiquata and Cerithium zonatum). 
Aji et al.

\section{Struktur Komunitas Moluska}

Indeks ekologi moluska di perairan Kepulauan Padaido dan Aimando ditunjukkan pada Tabel 3. Hasil penghitungan indeks keanekaragaman berkisar antara 3,078 (stasiun 14) - 3,952 (stasiun 7) sedangkan indeks dominan berkisar antara 0,02 (stasiun 7) - 0,093 (stasiun 14). Selanjutnya indeks kekayaan spesies dan kemerataan spesies tertinggi terdapat pada stasiun 7 dengan nilai 12,893 dan 0,991 . Sedangkan nilai terendah untuk indeks kekayaan spesies terdapat pada stasiun $8(9,041)$ dan indeks kemerataan spesies pada stasiun $14(0,768)$.

Hasil analisis cluster berdasarkan komposisi dan kelimpahan spesies moluska pada masing-masing stasiun dengan cut off $40 \%$ terdapat 6 kelompok yang dapat dilihat pada Gambar 8. Pada cut off $40 \%$ sudah dapat terlihat pemisahan stasiun ke dalam beberapa kelompok yaitu stasiun 3 dan 4 memiliki nilai kesamaan tertinggi $(64.3 \%)$ diikuti oleh stasiun 1 dan 2 (64.1\%), sedangkan stasiun 7 yang terdapat di Pulau Pai memiliki kesamaan yang paling rendah dibandingkan dengan stasiun lainnya

Tabel 3. Indeks ekologi moluska di 15 stasiun.

Table 3. Mollusca ecology index in 15 stations

\begin{tabular}{ccccc}
\hline Stasiun & $\begin{array}{c}\text { Richness } \\
\text { (Margalef) }(\mathbf{d})\end{array}$ & $\begin{array}{c}\text { Pielou's evenness } \\
\left(\mathbf{J}^{\prime}\right)\end{array}$ & $\begin{array}{c}\text { Shannon } \\
\text { H'(loge) }\end{array}$ & $\begin{array}{c}\text { Simpson } \\
(\mathbf{D})\end{array}$ \\
\hline 1 & 10.565 & 0.838 & 3.262 & 0.078 \\
2 & 10.881 & 0.902 & 3.547 & 0.044 \\
3 & 10.278 & 0.959 & 3.583 & 0.037 \\
4 & 9.823 & 0.969 & 3.573 & 0.033 \\
5 & 10.156 & 0.873 & 3.304 & 0.083 \\
6 & 11.235 & 0.971 & 3.739 & 0.028 \\
7 & 12.893 & 0.991 & 3.952 & 0.020 \\
8 & 9.041 & 0.972 & 3.485 & 0.035 \\
9 & 9.074 & 0.940 & 3.419 & 0.043 \\
10 & 10.883 & 0.976 & 3.714 & 0.027 \\
11 & 9.886 & 0.907 & 3.412 & 0.053 \\
12 & 9.156 & 0.987 & 3.511 & 0.032 \\
13 & 9.558 & 0.982 & 3.571 & 0.030 \\
14 & 10.281 & 0.768 & 3.078 & 0.093 \\
15 & 10.224 & 0.875 & 3.440 & 0.048 \\
\hline
\end{tabular}

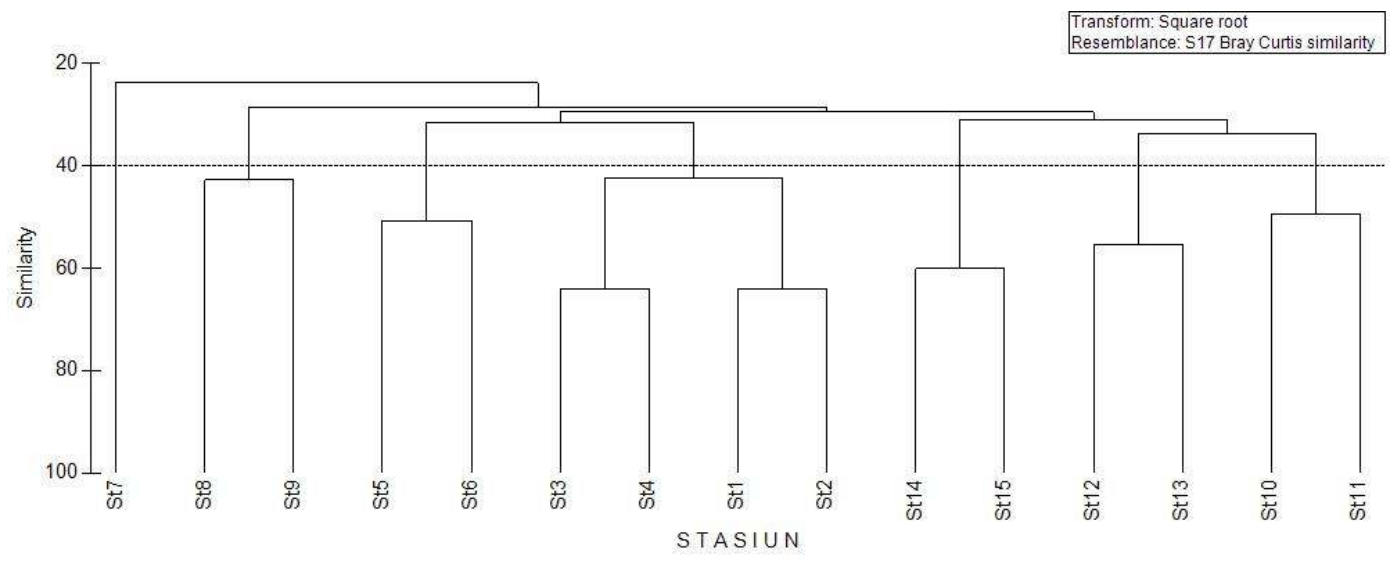

Gambar 8. Analisis dendrogram Bray-Curtis.

Figure 8. Analysis of dendrogram Bray-Curtis. 


\section{Pembahasan}

Jumlah individu dan jumlah spesies terbanyak terdapat pada Pulau Padaidori (stasiun 14 dan 15). Hal ini disebabkan karena lokasi sampling Pulau Padaidori jauh dari daerah pemukiman dan masyarakat nelayan. Masyarakat Padaidori lebih senang mencari ikan di laut daripada siput dan kerang. Selain itu tingginya jumlah individu ini dikarenakan adanya dominansi spesies gastropoda Cerithium zonatum dari Famili Cerithiidae yang melimpah bila dibandingkan dengan spesies lainnya dan kondisi substrat di stasiun 14 dan 15 yang sesuai yakni pasir kasar hingga berlumpur. Berdasarkan penelitian yang dilakukan oleh Widiyanto et al. (2016) bahwa $C$. zonatum ditemukan di perairan dengan bahan organik yang melimpah dan kondisi substrat kasar seperti pasir hingga lumpur. Selain itu spesies ini juga tidak ditangkap oleh nelayan baik untuk konsumsi maupun hiasan karena ukurannya yang terlalu kecil dengan cangkang yang keras serta bentuk cangkang yang kurang bagus. Secara umum, C. zonatum termasuk dalam kelompok opportunistic feeder dengan mobilitas yang rendah. $C$. zonatum ini memakan serasah lamun dan perifiton termasuk mikroalga dan filament alga hijau (Chang 2010). Oleh karena itu, stasiun 14 dan 15 yang memiliki hamparan lamun dan substrat berpasir merupakan habitat yang cocok bagi $C$. zonatum.

Gastropoda Monetaria annulus dari famili Cypraeidae dan Conomurex luhuanus dari famili Strombidae memiliki distribusi lokal yang luas di seluruh stasiun penelitian. Kedua spesies ini merupakan siput yang banyak ditangkap oleh nelayan lokal karena bernilai ekonomis penting. $M$. annulus digunakan oleh masyarakat biak untuk hiasan kerajinan tangan karena bentuknya yang indah. Adapun $C$. luhuanus sebagai bahan konsumsi dan termasuk ke dalam spesies yang memiliki nilai ekonomi (Thangevelu 2015). Walaupun merupakan siput yang dicari oleh nelayan lokal namun sebaran kedua spesies ini masih luas. Hal ini terbukti dengan masih ditemukannya jumlah individu $M$. annulus dan $C$. luhuanus, masing-masing sebesar 61 dan 22 individu selama sampling pada penelitian ini.

Distribusi M. annulus cukup luas dari daerah tropis sampai subtropis di Indo Pasifik Barat (Schilder dan Schilder 1939). Berdasarkan pengamatan saat penelitian, spesies ini banyak dijumpai di daerah intertidal dan menghuni daerah pantai (berpasir dan berlumpur) maupun reef flat yang terdapat lamun maupun patahan karang. Pada penelitian ini, kepadatan M. annulus mencapai 4,06 individu $/ \mathrm{m}^{2}$. Kepadatan ini lebih rendah jika dibandingkan dengan kepadatan $M$. annulus di daerah tropis Pulau Sulangan Philipina mencapai $8.4 \pm 0.3$ individu/m2 (Sibugan 2015). Masa reproduksi $M$. annulus ini berlangsung sepanjang tahun di daerah tropis maupun subtropis. Hal ini dibuktikan oleh studi dari Katoh (1989) di Jepang yang menemukan betina dewasa pada fase matang gonad maupun individu juvenil selama periode penelitiannya (April 1984 - Maret 1986).

Distribusi gastropoda Strombidae yang luas yaitu hampir dijumpai di setiap stasiun penelitian yaitu Conomurex luhuanus, Gibberulus gibbosus, Canarium labiatus, C. mutabilis, C. urceus, dan Lentigo lentiginosus. Seperti anggota Famili Strombidae yang lainnya yang mampu beradaptasi dengan baik, $C$. luhuanus merupakan spesies siput yang paling dominan ditemukan pada daerah pesisir (Aji dan Widyastuti 2017; Analuddin et al. 2013). Kelompok siput ini menghuni padang lamun dan memakan alga atau material detritus pada substrat berlumpur, berpasir atau pecahan karang. Taksa ini cenderung berkelompok dalam jumlah yang melimpah bila kondisi lingkungannya sesuai (Cob et al. 2014). Telur siput Strombidae berjumlah banyak dan berukuran kecil dalam bentuk untaian tabung panjang dan kenyal yang biasanya tertutupi oleh butiran pasir yang kemudian akan menetas menjadi bentuk planktonik (Cob et al. 2014). Pada fase planktonik penyebaran spesies ini terbantu oleh aliran arus sehingga penyebaran siput Strombidae pada daerah penelitian ini cukup luas.

Anadara antiquata dari famili Arcidae merupakan kelompok bivalvia dengan sebaran terluas yaitu ditemukan di 12 stasiun penelitian. Anadara antiquata memijah sepanjang tahun di perairan Padaido dengan puncak pemijahan bulan September dan Oktober (Widyastuti 2011). Individu yang ditemukan melimpah sebanyak 633 di daerah padang lamun selama penelitian pada tahun 2009 (Widyastuti 2011).

Kepadatan individu moluska di Padaido Aimando 15 individu $/ \mathrm{m}^{2}$ lebih besar bila dibandingkan dengan yang ditemukan di perairan Biak selatan sebesar 11 individu $/ \mathrm{m}^{2}$ (Aji dan Widyastuti 2017). Hal ini disebabkan karena perairan di Biak selatan lebih terpengaruh oleh aktifitas manusia karena dekat dengan daerah perkotaan apabila dibandingkan dengan daerah kepualauan Padaido Aimando yang tergolong masih alami.

Dari penelitian ini didapatkan 239 spesies moluska yang terbagi dalam dua kelas gastropoda 
sebanyak 177 spesies dan bivalvia sebanyak 62 spesies. Jumlah spesies yang ditemukan di perairan Kepulauan Padaido Aimando ini cukup melimpah bila dibandingkan dengan penelitian serupa yang dilakukan di daerah lain. Beberapa penelitian keanekaragaman moluska yang pernah dilakukan di perairan Biak Selatan Papua mendapatkan 94 spesies (Aji dan Widyastuti 2017); 103 spesies di Kepulauan Kei Kecil, Maluku Tenggara (Kusnadi et al. 2008); 85 spesies di Biak timur, Papua (Widyastuti et al. 2013); 128 spesies di Likupang, Sulawesi Utara (Arbi 2009); 182 spesies di kepulauan Talise, Sulawesi Utara (Arbi 2011); 83 spesies di Natuna, Kepulauan Riau (Mudjiono 2009) dan 31 spesies di pantai Sanur Bali (Istiqlal et al. 2013).

Nilai Indeks keanekaragaman spesies $(\mathrm{H})$ yang didapatkan dari area penelitian sangat tinggi dengan berkisar dari 3,078 (stasiun14) - 3,952 (stasiun 7). Menurut Daget (1976), nilai H diatas 2 maka nilai keanekaragaman spesiesnya termasuk dalam kategori tinggi. Nilai indeks diversitas yang tinggi menunjukan kestabilan komunitas yang terbentuk sehingga tetap dapat mempertahankannya walau terdapat gangguan pada ekosistem (Pavoine and Bonsall 2011). Tingginya nilai indeks diversitas spesies moluska di perairan Padaido Aimando ini dikarenakan jumlah individu diantara setiap spesies yang hampir sama atau merata dan sedikit spesies yang mendominasi.

Indeks kemerataan spesies $(\mathrm{J})$ berkisar antara 0,838 (stasiun 1) - 0,991 (stasiun7). Apabila nilai J mendekati angka 1 maka suatu komunitas di tempat tersebut dikatakan stabil dan bila mendekati angka 0 maka dikatakan tidak stabil. Sebaran fauna yang merata atau seimbang apabila nilai J berkisar antara 0,6 - 0,8 (Odum 1963). Oleh karena itu dapat dikatakan bahwa penyebaran spesies moluska di perairan Padaido Aimando termasuk merata yang artinya bahwa jumlah individu pada setiap spesies moluska yang ditemukan di daerah penelitian jumlahnya relatif sama atau merata. Hal ini dikarenakan kondisi habitat yang relatif sama dan cukup sesuai untuk spesies moluska gastropoda maupun bivalvia.

Indek kekayaan spesies tertinggi terdapat pada stasiun $7(12,893)$ dan terendah pada stasiun $8(9,041)$. Berdasarkan kriteria apabila jika nilai indeks kekayaan spesies di atas 8,57 termasuk dalam kategori tinggi (Mason et al. 2005) sehingga dapat disimpulkan kekayaan spesies di perairan Padaido Aimando termasuk melimpah. Semakin banyak jumlah spesies yang ditemukan maka akan semakin tinggi nilai indeks kekayaan spesiesnya. Stasiun 7 memiliki 54 spesies dan stasiun 8 memiliki spesies moluska terendah dari semua 232 stasiun yaitu 36 spesies. Tingginya jumlah spesies di perairan Padaido Aimando dipengaruhi oleh heterogennya kondisi substrat serta spesies lamun yang ditemukan. Hal tersebut menjadikannya sebagai habitat yang sesuai bagi berbagai spesies moluska.

Nilai indeks dominansi tertinggi terdapat pada stasiun $14(0,093)$ dan terendah pada stasiun 7 (0,020). Hal ini menunjukkan tingginya dominansi spesies pada stasiun 14 dibandingkan dengan stasiun lainnya. Pada stasiun 14 terdapat spesies Cerithium zonatum yang banyak tersebar di daerah padang lamun. Jumlah spesies pada stasiun 14 cukup melimpah tetapi indeks diversitasnya rendah, hal ini disebabkan adanya dominansi spesies Cerithium zonatum, sedangkan pada stasiun 7 tidak ditemukan spesies yang dominan sehingga indek keanekaragamannya cukup tinggi.

Adapun kesamaan tertinggi terdapat pada stasiun 3 dan 4 diikuti oleh stasiun 1 dan 2. Hal tersebut dikarenakan lokasi stasiun 3 dan 4 maupun stasiun 1 dan 2 cukup berdekatan satu sama lain. Jenis maupun tutupan lamunnya pun juga tidak jauh berbeda sehingga spesies moluska yang ditemukan hampir mirip diantara stasiun tersebut. Lamun memiliki peranan penting dalam menyusun ekosistem perairan laut, mulai dari produksi primer, penyedia tempat untuk feeding, spawning dan nursery untuk hewan invertebrata seperti Moluska (Cullen-Unsworth and Unsworth, 2013; Kendrick et al. 2016; dan Urra et al. 2013).

\section{Kesimpulan}

Jumlah spesies yang ditemukan pada kelas gastropoda (177) lebih banyak dibandingkan kelas bivalvia (62). Spesies moluska yang ditemukan pada gastropoda didominasi oleh famili Nassariidae sedangkan untuk bivalvia oleh famili Veneridae. Kepadatan moluska (gastropoda dan bivalvia) cukup tinggi di perairan Kepulauan Aimando Padaido. Namun, di beberapa lokasi penelitian kepadatannya sangat rendah dan distribusinya tidak merata. Hal ini dikarenakan jenis substrat tidak sesuai dan berdasarkan pengamatan lapangan ditemukan adanya indikasi eksploitasi yang berlebihan dari masyarakat sekitar. Oleh karena itu, diperlukan kajian yang lebih mendalam untuk menjaga biota moluska dari ancaman antropogenik dan tercapai pengelolaan yang lestari.

\section{Persantunan}

Kegiatan penelitian ini dibiayai oleh DIPA UPT. Loka Konservasi Biota Laut LIPI pada tahun anggaran 2014. Kami mengucapkan banyak terima 
kasih kepada staf peneliti, administrasi maupun teknisi dari UPT LKBL Biak yang terlibat. Begitu pula kami juga mengucapkan banyak terima kasih untuk saran dan koreksi dari reviewer sehingga makalah ini layak untuk diterbitkan.

\section{Daftar Pustaka}

Abbott, R.T. and P. Dance. 1990. Compendium of Seashell. Crawford House Pres, Australia: $411 \mathrm{pp}$.

Aji, L. P and A. Widyastuti, 2017. Mollusc diversity in coastal ecosystem of South Biak, Papua. Oseanologi and Limnologi di Indonesia 2(1): 25-37.

Analuddin, K., Nasarudin, W. Masa, W.O. Sarlyiana and S. Rahim. 2013. The Spatial Trends in the Community Structure of Gastropod Assemblages the Coastal Area of Tomia Island, Wakatobi Marine National Park, Indonesia. International Journal of Development Research 3(11): 162-167

Arbi, U. Y. 2009. Komunitas moluska di padang lamun perairan Likupang, Sulawesi Utara. Oseanologi and Limnologi di Indonesia 35(3): 417-434.

Arbi, U.Y. 2011. Struktur komunitas moluska di padang lamun perairan Pulau Talise, Sulawesi Utara. Oseanologi dan Limnologi di Indonesia 37(1): 71-89.

Chang, C. H. 2010. The biology of the snail Cerithium zonatum in an intertidal zone of Green Island. Master thesis. National Sun Yat-sen University. China

Cob Z., C., A. Arshaad, J. S. Bujang, and M. A. Ghaffar. 2014, Spatial and temporal variations in Strombus canarium (Gastropoda: Strombidae) abundance at Merambong Seagrass bed, Malaysia. Sains malaysiana 43(4): 503-511

Cullen-Unsworth, L., and R. Unsworth. 2013. Seagrass meadows, ecosystem services, and sustainability. Environment: Science and Policy for Sustainable Development 55(3), 14-28.

Daget, J. 1976. Les modeles mathematiques enecologie. Masson, Coll. Ecologie 8, Paris: $172 \mathrm{pp}$

Dharma, B. 2005. Recent and Fossil Indonesian Shells. Conchbooks, Hackenheim, Germany: $424 \mathrm{pp}$.

Huber, M. 2010. Compendium of bivalves: A fullcolor guide to 3'300 of the world's marine bivalves, A status on bivalvia after 250 years of research. ConchBooks Hackenheim. Germany. 901 pp.
Istiqlal, B. Y., D. S. Yusup, and N. M. Suartini. 2013. Distribusi horizontal moluska di kawasan padang lamun pantai Merta Segara Sanur, Denpasar. Jurnal Biologi XVII(1): 1014.

Katoh, M. 1989. Life history of the golden ring cowry Cypraea annulus (Mollusca: Gastropoda) on Okinawa Island, Japan. Marine Biology 101: 227-234

Kendrick, G. A., M. Vanderklift, D. Bearham., J. Mclaughlin, J. Greenwood, , C. Säwström, and A. Howard . 2016. Benthic primary productivity: production and herbivory of seagrasses, macroalgae and microalgae. Report of, 2(4).

KMNLH. 2004. Keputusan Menteri Negara Lingkungan Hidup Nomor 200 Tahun 2004 Tentang Kriteria Baku Kerusakan dan Pedoman Penentuan Status Padang Lamun.

Kusnadi, A., T. Triandiza, dan U. E. Hernawan. 2008. Inventarisasi Jenis dan Potensi Moluska Padang Lamun di Kepulauan Kei Kecil, Maluku Tenggara. Biodiversitas 9 (1): 30-34.

Mason, N.W.H., D. Mouillot, W.G. Lee and J.B. Wilson. 2005. Functional richness, functional evenness and functional divergence: The primary components of functional diversity. OIKOS 111: 112-118.

Mudjiono. 2009. Telaah komunitas moluska di rataan terumbu perairan kepulauan Natuna Besar, Kabupaten Natuna. Oseanologi dan Limnologi di Indonesia 35(2): 151-166.

Pavoine, S., and M. B. Bonsall. 2011. Measuring biodiversity to explain community assembly: a unified approach. Biological Reviews 86(4): 792-812.

Poppe, G. T., P. Poppe, and S. P. Tagaro. 2014. 1000 Shells Exceptionals from the Philippines. Conch Books Hackenheim. Germany. 897 pp.

Sibugan, V.S., 2015. Ecology of Monetaria annulus (Linnaeus, 1758) (Mollusca: Gastropoda: Cypraeidae) from Temperate to Tropical Areas (Doctoral dissertation, Kagoshima University Japan).

Schilder, M., and P. F. Schilder. 1936. Revision of the Genus Monetaria (Cypræidæ). In Proceedings of the Zoological Society of London (Vol. 106, No. 4, pp. 1113-1135). Oxford, UK: Blackwell Publishing Ltd.

Thangavelu, A. E. 2015. 'Unshelling the past'-an archaeological study of shellfish assemblages from Caution Bay, Papua New Guinea (Doctoral dissertation, University of Southern Queensland). 
Tucker, J.K and M. J. Tenorio. 2013. Illustrated Catalog of the Living Cone Shells. MdM Publishing. Wellington FL. Pp 517

Urra, J., Á. M. Ramírez, P. Marina, C. Salas, S. Gofas, and J. L. Rueda. 2013. Highly diverse molluscan assemblages of Posidoniaoceanica meadows in northwestern Alboran Sea (W Mediterranean): Seasonal dynamics and environmental drivers. Estuarine, Coastal and Shelf Science 117: 136-147.

Widyastuti, A. 2011. Perkembangan gonad kerang darah (Anadara antiquata) di perairan Pulau Auki, Kepulauan Padaido, Biak, Papua.
Oseanologi dan Limnologi di Indonesia 37(1): 1-17

Widyastuti, A., A. B. Sitepu dan L. P. Aji. 2013. Keragaman Moluska Pesisir Biak. UPT Loka Konservasi Biota Laut Biak - Puslit Oseanografi LIPI. Laporan. 112 pp.

Widiyanto, A., I. Karlina dan R. D. Putra. 2016. Keanekaragaman gastropoda pada vegetasi mangrove di desa Bintan Buyu, Kabupaten Bintan. Repositori tugas akhir mahasiswa Umrah.

Wilson, B. 1993. Australian Marine Shells: Prosobranch Gastropods. Vol I. Odysey Publishing. Australia. 407 pp. 